\title{
PEMBERDAYAAN MASYARAKAT BERBASIS PERTANIAN MELALUI PEMBUATAN NUGGET JANTUNG PISANG DENGAN SUBSTITUSI KACANG TANAH DI DESA MOLAMAHU, KECAMATAN PULUBALA, KABUPATEN GORONTALO, PROVINSI GORONTALO
}

\author{
Community Empowerment Based On Agriculture Throught The Making Of Banana Heart \\ Nugget With Soil Bean Subtitution In Molamahu, Pulubala District, Subdistrict Gorontalo, \\ Gorontalo Province
}

\author{
Abdul Azis Hasan'), Adnan Angelen ${ }^{2)}$, Desi Arisanti'), Syaiful Umela ${ }^{4)}$, Ika Ikthora \\ Angelia ${ }^{5)}$, Rosdiani Azis ${ }^{6}$, Ingka Rizkyani Akolo ${ }^{7)}$ \\ 1, 2, 3, 4, 5, 6, 7, Staf Pengajar Program Studi Teknologi Hasil Pertanian, Politeknik Gorontalo \\ Jl. Muchlis Rahim Desa Panggulo, Kec. Botupingge, Kab. Bone Bolango, Prov. Gorontalo \\ Email : abdazizhasan@poligon.ac.id
}

\begin{abstract}
ABSTRAK
Kabupaten Gorontalo merupakan salah satu wilayah di Provinsi Gorontalo yang memiliki potensi besar untuk pengembangan pertanian. Kecamatan Pulubala adalah salah satu kecamatan yang dipilih sebagai lokasi kegiatan Program Kemitraan Masyarakat (PKM). Luas wilayah Kecamatan Pulubala adalah $221 \mathrm{~km} 2$ atau sebesar 10,3\% dari luas wilayah Kabupaten Gorontalo. Dilihat dari morfologi wilayah kecamatan Pulubala didominasi daerah dataran tinggi.

Desa Molamahu di Kecamatan Pulubala terletak relatif jauh dari pusat Kabupaten Gorontalo yang berjarak sekitar $\pm 26 \mathrm{~km}$. Kondisi ini menyebabkan Petugas Penyuluh Pertanian jarang datang ke desa ini. Berdasarkan hasil tersebut diketahui bahwa dalam beberapa tahun terakhir tidak pernah dilakukan penyuluhan pertanian tentang pengolahan produk-produk pertanian khususnya jantung pisang. Kenyataan ini semakin membenarkan kondisi petani yang tidak memiliki kemampuan dan pengetahuan tentang cara-cara mengolah jantung pisang menjadi produk yang bernilai ekonomi yang baik. Diharapkan pada akhir kegiatan Program Kemitraan kepada Masyarakat (PKM) di Desa Molamahu ini adalah : Para anggota kelompok petani dapat dan terampil melakukan melaksanakan pengolahan jantung pisang yang merupakan bagian dari tanaman pisang serta para anggota kelompok terampil dan mandiri dalam mengolah berbagai produk jantung pisang menjadi nugget jantung pisang dengan penambahan kacang tanah dan terbentuknya unit usaha produktif pada kelompok mitra khususnya yang dikelola ibu-ibu rumah tangga keluarga mitra.
\end{abstract}

Kata kunci: Jantung pisang, diversifikasi produk, nilai ekonomi

\section{ABSTRACT}

Gorontalo Regency is one of the regions in Gorontalo Province that has great potential for agricultural development. Pulubala District is one of the sub-districts chosen as the location of the Community Partnership Program (PKM). The area of Pulubala District is $221 \mathrm{~km} 2 \mathrm{or}$ $10.3 \%$ of the total area of Gorontalo Regency. Judging from the morphology of the Pulubala sub-district the area is dominated by highland Molamahu Village in Pulubala District is 
located relatively far from the center of Gorontalo Regency which is about $\pm 26 \mathrm{~km}$. This condition causes Agriculture Extension Officers to rarely come to this village. Based on these results, it is known that in recent years agricultural counseling has never been carried out about processing agricultural products, especially the heart of the banana. This fact further justifies the condition of farmers who do not have the ability and knowledge of ways to process banana heart into good economic value products. It is expected that at the end of the activity the Community Partnership Program (PKM) in Molamahu Village will be: The members of the farmer group can and skillfully carry out the processing of the banana heart which is part of the banana plant and skilled and independent group members in processing various banana heart products into Banana heart nuggets with the addition of peanuts and the formation of productive business units in partner groups, especially those managed by the partners' housewives.

Keywords: Banana heart, product diversification, economic value

\section{PENDAHULUAN}

Indonesia merupakan penghasil pisang terbesar keenam di dunia. Bahkan di Asia, Indonesia merupakan penghasil pisang terbesar, karena hampir $50 \%$ produksi pisang di Asia, dihasilkan oleh Indonesia, dan setiap tahun produksinya terus meningkat. Pisang juga memiliki kandungan gizi yang tinggi, dan memiliki tingkat antioksidan yang cukup tinggi. Pisang menjadi buah yang penting di masyarakat Indonesia, karena pisang merupakan buah yang sering dikonsumsi dibandingkan dengan buah yang lain dan dikonsumsi tanpa memperhatikan tingkat sosial.

Bukan hanya buah pisang saja yang memiliki kandungan gizi yang tinggi, namun bagian lain dari pohon pisang. Seperti Jantung pisang yang merupakan bagian dari tanaman pisang yang dapat diolah menjadi sayuran. Banyaknya produksi jantung pisang di desa Molamahu yang belum mengalami diversifikasi sehingga dalam hal ini jantung pisang dapat dimanfaatkan menjadi suatu bahan/produk makanan oleh masyarakat atau unit usaha mikro.

Jantung pisang merupakan salah satu satu bagian dari tanaman pisang yang

selama ini keberadaannya terabaikan. Kita ketahui bersama bahwa jantung pisang merupakan bagian tanaman pisang yang cukup banyak jumlahnya. Ukuran jantung pisang sekitar $25-40 \mathrm{~cm}$ dengan ukur lilit tengah jantung $12-25 \mathrm{~cm}$. Jantung pisang mempunyai cairan berwarna jernih dan

\begin{tabular}{|c|c|}
\hline Komponen & Nilai \\
\hline Energi & $31 \mathrm{Kkal}$ \\
\hline Protein & $1,26 \mathrm{gr}$ \\
\hline Lemak & $0,35 \mathrm{gr}$ \\
\hline Karbohidrat & $8,31 \mathrm{gr}$ \\
\hline Kalsium & $6 \mathrm{mg}$ \\
\hline Besi & $0,4 \mathrm{mg}$ \\
\hline Fosfor & $50 \mathrm{mg}$ \\
\hline Vitamin A & $140 \mathrm{SSI}$ \\
\hline Vitamin B1 & $0.06 \mathrm{mg}$ \\
\hline Vitamin C & $9 \mathrm{mg}$ \\
\hline
\end{tabular}

akan menjadi pudar warnanya apabila jantung pisang terkena udara dari luar lingkungan sekitarnya (Panji R, 2012).

Tabel 1. Komposisi gizi jantung pisang per 100 gram

Sumber: Putro dan Rosita (2006)

Komponen penting lainnya yang terdapat pada jantung pisang adalah serat pangan yang sangat bermanfaat bagi kesehatan. Serat pangan sangat bermanfaat untuk memperlambat kecepatan pencernaan dalam usus, sehingga aliran energy ke

dalam tubuh menjadi konstan, memberikan perasaan kenyang yanga lebih lama, 
memperlambat keberadaan gula darah (glukosa), sehingga insulin yang dibutuhkan

untuk mengubah glukosa menjadi energy semakin sedikit, membantu mengendalikan berat badan dengan memperlambat timbulnya rasa lapar, meningkatkan kesehatan saluran pencernaan dengan cara meningkatkan

pergerakan usus besar, mengurangi resiko penyakit jantung, mengikat lemak dan kolesterol kemudian dikeluarkan melalui feses (Kusumaningtyas, dkk., 2016)

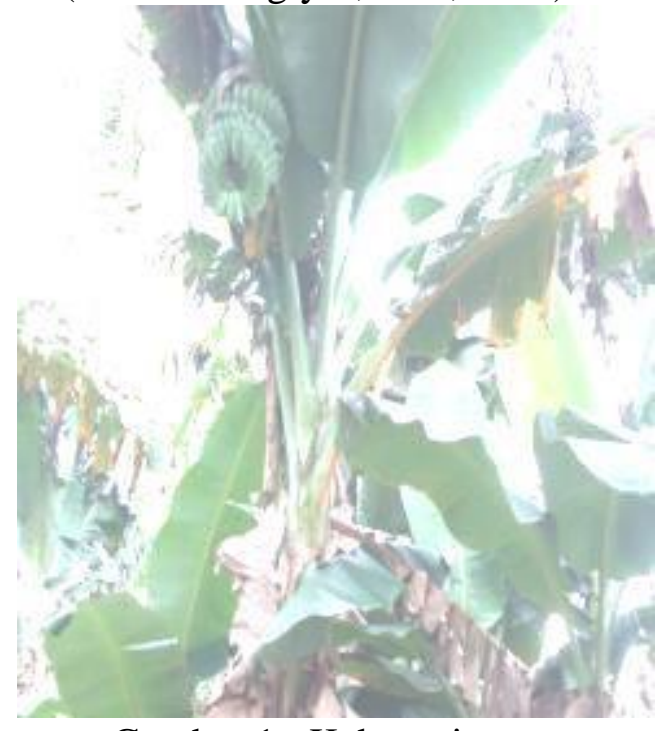

Gambar 1 : Kebun pisang

\section{Permasalahan Mitra}

Daerah yang menjadi sasaran adalah Desa Molamahu, Kecamatan Pulubala, Kabupaten Gorontalo, Provinsi Gorontalo. Secara geografi lokasi desa Mitra terletak relatif jauh dari pusat Kabupaten Gorontalo yang berjarak sekitar $\pm 26 \mathrm{~km}$. Kondisi ini menyebabkan Petugas Penyuluh Pertanian jarang datang ke desa ini. Berdasarkan hasil tersebut diketahui bahwa dalam beberapa tahun terakhir tidak pernah dilakukan penyuluhan pertanian tentang pengolahan produk-produk pertanian khususnya jantung pisang. Kenyataan ini semakin membenarkan kondisi petani yang tidak memiliki kemampuan dan pengetahuan tentang cara-cara mengolah jantung pisang menjadi produk yang bernilai ekonomi yang baik.
Desa ini memiliki tanaman pisang yang melimpah. Banyaknya kebun pisang di Desa Molamahu menjadi alasan tim pengusul untuk membuat pengabdian masyarakat di Desa tersebut melalui Program Kemitraan Masyarakat (PKM). Sehingga diharapkan melalui Program Kemitraan Masyarakat, keratifitas unit atau usaha mikro masyarakat di Desa Molamahu dapat lebih bernilai ekonomi dengan diadakannya pelatihan pembuatan produk lokal dari jantung pisang seperti nugget jantung pisang. Dengan kegiatan tersebut masyarakat akan semakin banyak tahu tentang bagaimana memanfaatkan produk lokal. Sehingga diharapkan dengan adanya pelatihan yang kemudian memajukan unit usaha di Desa Molamahu sehingga dapat menarik minat pembeli dan berdampak pada peningkatan penghasilan masyarakat.

Proposal kegiatan PKM yang akan diajukan bertujuan melakukan edukasi dan mencari solusi permasalahan yang dihadapi oleh kelompok mitra dan masyarakat di Desa Molamahu yang merupakan desa yang memiliki tanaman pisang melimpah di Kecamatan Pulubala. Setelah pengusul melakukan silaturahim dengan kelompok mitra maka diperoleh kesepakatan dalam menentukan permasalahan prioritas mitra khususnya bagaimana metode yang benar dalam memanfaatkan jantung pisang menjadi olahan makanan yang bernilai jual tinggi sehingga terbangun sikap kemandirian warga dengan membuat produk itu sendiri melalui kelompok binaan masyarakat. Selain itu mitra juga akan diberi pelatihan mengenai penerapan manajemen dan bekal ilmu pemasaran untuk menjadi seorang wirausaha dalam bidang teknologi pertanian. Sehingga selain kondisi lingkungan menjadi bersih diharapkan masing-masing kepala keluarga memiliki usaha sampingan dari hasil penjualan olahan jantung pisang tersebut sehingga bisa dijadikan tambahan pendapatan keluarga dan mampu mengurangi tingkat 
kemiskinan seperti yang diharapkan pemerintah pusat maupun daerah.

\section{SOLUSI DAN TARGET LUARAN}

Berdasarkan latar belakang di atas, maka solusi yang akan ditawarkan untuk menyelesaikan permasalahan yang dihadapi kelompok mitra berdasarkan prioritas permasalahan dalam program ini antara lain:

1. Upaya dalam mengatasi jantung pisang yang tidak dimanfaatkan oleh

kelompok mitra untuk dijadikan produk

olahan jantung pisang yang bermanfaat bagi peningkatan kesejahteraan keluarga,

2. Memberikan pemahaman dan pengetahuan kepada kelompok mitra bagaimana mengolah kulit pisang menjadi aneka olahan makanan yang bernilai jual tinggi

3. Kelompok mitra belum mengetahui bagaimana cara mengemas produk dan menjualnya oleh karena selain diadakan pelatihan pengolahan juga workshop mengenai teknik pengemasan hingga tahapan tata niaga.

\section{Luaran dan Target Capaian}

1. Produk hasil diversifikasi aneka produk olahan jantung pisang

2. Kelompok mitra memiliki kemandirian dan terampil dalam mengolah berbagai produk kulit pisang sehingga menghasilkan kualitas produk yang bernilai tawar tinggi di pasar serta meningkatkan kesejahteraan ekonomi kelompok mitra dan masyarakat

3. Peningkatan omzet pada kelompok mitra

4. Peningkatan kualitas produk olahan kulit pisang hingga mendapatkan PIRT

5. Publikasi ilmiah di jurnal nasional terakreditasi dan koran lokal

Tabel 2. Rencana Target Capaian Luaran

\begin{tabular}{|l|l|l|}
\hline No. & Jenis Luaran & $\begin{array}{l}\text { Indikator } \\
\text { Capaian }\end{array}$ \\
\hline 1 & $\begin{array}{l}\text { Publikasi ilmiah di jurnal } \\
\text { nasional (ber ISSN)1 }\end{array}$ & Published \\
\hline 2 & $\begin{array}{l}\text { Publikasi pada media masa } \\
\text { (cetak/elektronik) 2 }\end{array}$ & $\begin{array}{l}\text { Sudah } \\
\text { terbit }\end{array}$ \\
\hline 3 & $\begin{array}{l}\text { Peningkatan omzet pada } \\
\text { mitra yang bergeak dalam } \\
\text { bidang ekonomi 3) }\end{array}$ & Ada \\
\hline 4 & $\begin{array}{l}\text { Peningkatan kuantitas dan } \\
\text { kualitas produk 3) }\end{array}$ & Ada \\
\hline 5 & $\begin{array}{l}\text { Peningkatan pemahaman } \\
\text { dan ketrampilan } \\
\text { masyarakat 3 }\end{array}$ & Ada \\
\hline 6 & $\begin{array}{l}\text { Peningkatan (mitra } \\
\text { ketentraman/kesehatan } \\
\text { masyarakat sistem, } \\
\text { masyarakat umum) 3) }\end{array}$ & Ada \\
\hline 7 & $\begin{array}{l}\text { Jasa, model, rekayasa } \\
\text { sosial, Ada } \\
\text { produk/barang 4) }\end{array}$ & $\begin{array}{l}\text { Hak kekayaan intelektual } \\
\text { (paten, paten sederhana, } \\
\text { hak cipta, merek dagang, } \\
\text { rahasia dagang, desain } \\
\text { produk industry, } \\
\text { perlindungan varietas } \\
\text { tanaman, perlindungan } \\
\text { topografi 5) }\end{array}$ \\
\hline 9 & $\begin{array}{l}\text { Buku ajar 6) } \\
\text { Ada }\end{array}$ \\
\hline 8
\end{tabular}

1) Isi dengan tidak ada, draft, submitted, reviewed, atau accepted atau published

2) Isi dengan tidak ada, draft, proses editing atau sudah terbit

3) Isi dengan tidak ada atau tidak ada

4) Isi dengan tidak ada, draft, produk atau penerapan

5) Isi dengan tidak ada, draf, terdaftar, atau granted

6) Isi dengan tidak ada, draf, proses editing, atau sudah terbit berISBN

\section{METODE PELAKSANAAN}

Pengusul PKM telah melakukan penyusunan rencana metode yang akan dilakukan selama proses awal sosialisasi dan rencana selama kegiatan berlangsung. Tim pengusul PKM memiliki tujuan agar terjadi komunikasi timbal balik tentang bagaimana cara efektif untuk mengajak kelompok mitra ikut serta dalam kegiatan ini serta untuk mengetahui karakteristik 
para masyarakat di desa Molamahu. Kegiatan pelatihan menggunakan pemberian materi melalui ceramah, kemudian dilanjutkan dengan praktik langsung oleh para kelompok mitra. Cara ini dianggap efektif karena transfer pengetahuan yang diperoleh selama pelatihan akan lebih tersampaikan dengan baik jika peserta pelatihan itu sendiri yang menyampaikannya dan merasa bahwa kegiatan pelatihan tersebut bermanfaat bagi mereka.

Dalam kegiatan pelatihan ini, tim PKM memiliki kelompok mitra memiliki anggota minimal 3 orang. Tujuan dari pengelompokkan ini adalah agar kinerja mereka lebih mudah jika dilakukan dengan anggota yang sudah dikenal dengan baik, selain itu diharapkan agar jika nantinya mereka akan menumbuh kembangkan usaha

ini di desa Molamahu, mereka dapat bekerja sama mengelola usaha pengolahan kulit pisang menjadi berbagai produk olahan kulit pisang. Instrumen pelaksanaan masing-masing kelompok tersebut diberikan sama proporsinya, sehingga memudahkan mereka untuk melakukan kegiatan. Setiap peserta

pelatihan juga diharuskan untuk mengaplikasikan materi yang sudah diberikan tim PKM. Semua peserta ikut terlibat dan masing-masing kelompok melakukan pembagian kerja sendiri di dalam kelompoknya.

Tabel 3. Metodologi Pelaksanaan Kegiatan

\begin{tabular}{|l|l|l|l|l|}
\hline No & Materi & Metode & Evaluasi & $\begin{array}{l}\text { Alokasi } \\
\text { Waktu }\end{array}$ \\
\hline 1 & $\begin{array}{l}\text { Materi } \\
\text { mengenai } \\
\text { teknis } \\
\text { pengolahan } \\
\text { jantung } \\
\text { pisang }\end{array}$ & $\begin{array}{l}\text { Ceramah; } \\
\text { praktik }\end{array}$ & $\begin{array}{l}\text { Tanya } \\
\text { jawab }\end{array}$ & $\begin{array}{l}2 \times 60 \\
\text { menit }\end{array}$ \\
\hline 2 & $\begin{array}{l}\text { Workhsop } \\
\text { pengemasan } \\
\text { produk }\end{array}$ & $\begin{array}{l}\text { Ceramah; } \\
\text { praktik }\end{array}$ & $\begin{array}{l}\text { Tanya } \\
\text { jawab }\end{array}$ & $\begin{array}{l}2 \times 60 \\
\text { menit }\end{array}$ \\
\hline 3 & $\begin{array}{l}\text { Workshop } \\
\text { tata niaga } \\
\text { produk } \\
\text { rumput laut }\end{array}$ & $\begin{array}{l}\text { Ceramah; } \\
\text { praktik }\end{array}$ & $\begin{array}{l}\text { Tanya } \\
\text { jawab }\end{array}$ & $\begin{array}{l}2 \times 60 \\
\text { menit }\end{array}$ \\
\hline
\end{tabular}

\section{HASIL DAN PEMBAHASAN}

Pengabdian Masyarakat yang dilaksanakan oleh Program Studi Teknologi Hasil Pertanian Politeknik Gorontalo di Desa Molamahu Kecamatan Pulubala Kabupaten Gorontalo, menghasilkan produk nugget dari jantung pisang yanbg memiliki diagram pembuatan produk sebagai berikut :

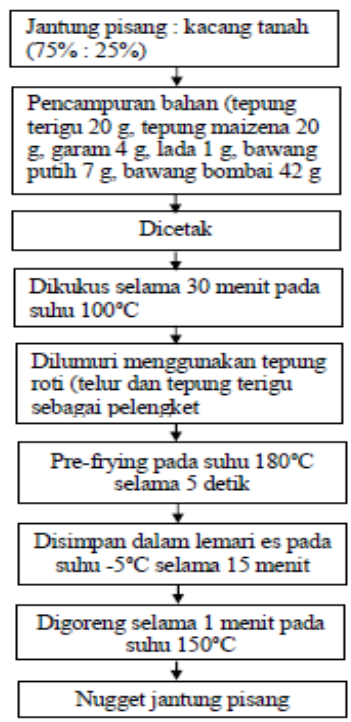

Gambar 2.Alur Pembuatan nugget jantung pisang

Adapun beberapa langkah yang digunakan untuk membantu Masyarakat setempat, berupa :

1. Pertama-tama diawali dengan penjelasan beberapa pemateri yang terdiri

dari dari pihak dosen Politeknik Gorontalo dan pihak Desa Molamahu.

2. Materi yang disampaikan berhubungan dengan cara penanganan terhadap hasil pertanian dan hasil pertanian yang pada saat tertentu overload seperti kacang tanah. Sedangkan hasil pertanian seperti pisang dimana pada tanaman pisang terdapat jantung pisang yang merupakan hasil salah satu produk unggulan Desa Molamahu Kecamatan Pulubala. Hasil pertanian ini dapat dimanfaatkan untuk dibuat menjadi produk dengan nilai jual yang tinggi. 
3. Kemudian dilanjutkan dengan Desiminasi teknologi pengolahan hasil pertanian oleh Dosen Politeknik Gorontalo dari Program Studi Teknologi Hasil Pertanian. Kegiatannya berupa demonstrasi pembuatan nugget jantung pisang. Anggota kelompok masyarakat setempat mengikuti dengan cermat setiap tahapan demo pembuatan berbagai produk olahan tersebut.

4. Program lanjutan setelah demo pembuatan produk tersebut adalah kegiatan pendampingan oleh para Dosen Program Studi Teknologi Hasil Pertanian Politeknik Gorontalo terhadap kelompok masyarakat Desa Molamahu yang akan dilakukan secara bertahap, Program pemdampingan ini berharap agar masyarakat lebih mengerti lagi penerapan/penggunaan teknologi tepat guna dalam pengolahan hasil pertanian, yang pada giliran selanjutnya diharapkan dapat membantu meningkatkan perekonomian masyarakat Desa Molamahu tersebut.

\section{DAFTAR PUSTAKA}

Kusumaningtyas, DR., Rengga RWD dan Suyitno H. 2010. Pengolahan limbah tanaman pisang (Musa paradisiacal) menjadi dendeng dan abon jantung pisang sebagai peluang wirausaha baru bagi masyarakat pedesaan. Jurnal Penerapan Teknologi dan Pembelajaran, 8 (2).

Panji, R. 2012. Sejuta manfaat jantung pisang.

http://makanansehat.com/manfaatjantung pisang-untuk-kesehatan-tubuh.

Putro, BE dan Rosita, T. 2006. Membuat dendeng rendah kolesterol dari jantung pisang. Agromedia Pustaka. Jakarta 